\title{
From the Mountain of YHWH to Israel's מנוחה: The Desert Itinerary of Numbers 10:11-36
}

\author{
ARIE C. LEDER (UFS, BLOEMFONTEIN)
}

\begin{abstract}
This essay argues that the post-Sinai itinerary narratives depicted in Numbers are organized into two clusters (Num 10:11-36 and 20:2222:1), both of which depict the first generation of Israelites of the exodus, and that the first of these functions as the conclusion to Num 1:1-10:10. The first narrative depicts a generation fully instructed and compliant with divine instruction (Num 1:1-10:10) that resumes the march that began on Passover night, upon the Lord's command given through Moses (10:13). The goal of the first itinerary cluster is the ark finding rest for the people (מנוחה, Num 10:33). Furthermore, this essay argues that the syntactical function of the itinerary verbs in Num 11:35 and 12:16 subordinate them to the theme of complaint and rebellion against authority, which begins in 11:1, and that therefore they do not depict the continuation of the journey that began in Num 10:12. It is within this narrative of complaint that the second itinerary cluster emerges, beginning in Num 20:22 and ending in 22:1, to depict the same generation as non-compliant and rebellious.
\end{abstract}

KEYWORDS: Numbers; itinerary; rest; first/second generation

\section{A INTRODUCTION}

Scholarship on the desert itineraries of Exodus and Numbers generally seeks to clarify perceived compositional difficulties by understanding the interactions of the Pentateuch's underlying literary traditions. Frank Moore Cross suggests that the itineraries function as structural elements of P: a framing device composed of six formulaic headings before (Exod 12:37a; 13:20; 14:1-2; 15:22a; $16: 1 ; 17: 1$ ) and six after Sinai (Exod 19:2; Num 10:12; 20:1a; 20:22; 21:10-11; 22:1). ${ }^{1}$ Graham I. Davies accepts only Exod 19:1, Num 10:12; 20:1a and 22:1

* Article submitted: 1/07/2016; accepted: 1/09/2016. To cite: Arie C. Leder, "From the Mountain of YHWH to Israel's מנוחה: The Desert Itinerary of Numbers 10:11-36," OTE 29 (3) 2016: 513-534. Doi: http://dx.doi.org/10.17159/2312-3621/2016 / v29n $3 \mathrm{a} 10$

1 Frank M. Cross, Canaanite Myth and Hebrew Epic: Essays in the History of the Religion of Israel (Cambridge, Mass.: Cambridge University Press, 1973), 308, 317, characterized by the formulaic, "They departed (way-yis `u) from PN and encamped (way-ya 'anu) at PN." According to Cross, the wording deviates from this pattern occasionally. See also George W. Coats, "The Wilderness Itinerary," CBQ 34 (1972): 
514 Leder, "From the Mountain of YHWH," OTE 29/3 (2016): 513-534

as $\mathrm{P}$, leaving the rest to $\mathrm{D}$, a conclusion which suggests that $\mathrm{P}$ was concerned only with transitions and that $\mathrm{D}$ composed the desert tradition as one single movement ${ }^{2}$ to serve as a transition between the desert narrative and the conquest. ${ }^{3}$ Most recently, Thomas Dozeman explores "whether there is literary evidence for the creative role of a redactor in relating $\mathrm{P}$ and non-P versions of the wilderness journey in Exodus and Numbers." 4 He examines three geographical locations of the wilderness journey that stand out because they disrupt the plot of the journey (Exod 4:1-2;16:1b and 17:1a; Num 10:11-12) and concludes "that editors use the Priestly itineraries to reshape the Non-P literature; and that the process of editing is ... a creative undertaking in its own right.",

Because these studies examine the itineraries for historical-compositional purposes, two sets of questions are generally not asked. First, how do the itineraries, as woven into the final text function within the received narrative? Dozeman, for example, acknowledges Coats's study of the structural patterns exhibited by the itineraries, but agrees with Walsh that his approach "cannot provide insight into the composition or the authorship of the itineraries." Coats's interest, however, is not primarily authorial or compositional; his struc-

147; and for $15: 22 ; 16: 1 ; 17: 1 ; 19: 1-2$, Mark S. Smith, The Pilgrimage Pattern in Exodus (Sheffield: Sheffield Academic Press, 1997), 227, 232. Cross's list of stations fails to account for the נסע travel notices which occur in Exod 14 and Num 20-22. Jerome T. Walsh, "From Egypt to Moab: A Source Critical Analysis of the Wilderness Itinerary," CBQ 39 (1977): 21, lists Exod 12:37; 13:17-18a, 20; 14:2; 15:22, 23, $27 ; 16: 1 ; 17: 1 ; 19: 1-2$; Num 10:12, 33; 11:35; 12:16; 14:25; 20:1a, 22; 21:4, 10, 11, 12, 13, 16, 18b, 19b, 20, 33; 22:1; Coats, "Wilderness," 135, lists Exod 12:37a; 13:20; 15:22a, 27; 16:1; 17:1ab*; 19:2; Num 11:35; 12:16; 20:1, 22; 21:4a.10, 11, 12, 13, 16, 18b, 19a $19 \mathrm{~b}, 20 ; 22: 11$. He also lists Exod 14:2; 15:23a*; 19:1 and Num 10:12. Although similar, those listed by Graham I. Davies. "The Wilderness Itineraries and the Composition of the Pentateuch," VT 33 (1983): 1-13, are not the same.

2 Davies, "Wilderness," 12; William Johnstone, "From the Sea to the Mountain: Exodus 15,22-19,2: A Case-Study in Editorial Techniques," in Studies in the Book of Exodus (ed. Marc Vervenne; Louvain: Peeters, 1996), 245-263, proposes that a pre-P version included only Exod 15:22 and 19:2b and that D supplied the intervening material.

3 See Davies, "Wilderness," 8, and Coats, "Wilderness," 136, for the function of the chain in its present form. For the itineraries in Deuteronomy, see Patrick D. Miller, "The Wilderness Journey in Deuteronomy: Style, Structure, and Theology in Deuteronomy 1-3," CovQ 55 (1997): 50-68.

4 Thomas B. Dozeman, "The Priestly Wilderness Itineraries and the Composition of the Pentateuch," in The Pentateuch: International Perspectives on Current Research, ed. Thomas B. Dozeman, Konrad Schmid, and Baruch J. Schwarz (Tübingen: Mohr Siebeck, 2011), 262.

5 Dozeman, "Priestly," 287-288. The location of the Sinai pericope itself "breaks the plot" of a single journey and is thus itself a creative redaction of that journey. 
tural and source-critical studies are subordinate arguments in favor of the unity of the canonical itinerary chain and its function in unifying various traditions in terms of royal military journeys depicted in Assyrian annals. ${ }^{6}$ Second, and related, historical-compositional studies generally examine itinerary markers without regard for the narrative discourse in which the itineraries are embedded, a discourse in which the wayyiqtol and $w^{e}$ qatal forms have functions that go beyond redactional interests. ${ }^{7}$

Where Coats pursued the unity of a single wilderness itinerary from Egypt to Moab, this article examines the canonical shape ${ }^{8}$ of the pentateuchal depiction of Israel's wilderness journeys, in which the so-called Sinai pericope

6 This explains the singular "itinerary" in the title of Coats" article, "Wilderness," 135, 147-148. The so-called Sinai pericope, Coats argues, is but one, albeit long, stage on this itinerary (Coats, "Wilderness," 149). The association of the itineraries and the military annals is also found in Graham I. Davies, "The Wilderness Itineraries: A Comparative Study," TynBul 25 (1974): 80; and Albrecht Goetze, "An Old Babylonian Itinerary," JCS 8 (1954): 51-72. Two recent studies have engaged the function of the itineraries as military journeys. Arie C. Leder, "The Desert Itinerary Notices of Exodus: Their Narrative, Semiotic, and Theological Functions," EstBib 68/3 (2010): 291-311; and Angela R. Roskop, The Wilderness Itineraries: Genre, Geography and the Growth of the Torah, HACL 3 (Winona Lake: Eisenbrauns, 2011).

7 This describes the studies mentioned above. Olivier Artus, Etudes sur le livre des Nombres: Récit, Histoire et Loi en Nb 13,1-20-13, OBO (Göttingen: VandenHoeck \& Ruprecht, 1997), 24, does not distinguish between the wayyiqtol and qatal forms of נסע. For example, he reads Num 12:16 as describing Israel's arrival. Roskop, Wilderness Itineraries, 208, also appears to read the qatal forms on the same discourse level as the wayyiqtol forms. For the hierarchical organization of the clauses used here, Alviero Niccacci, The Syntax of the Verb in Classical Hebrew Prose, JSOTSup 86, trans. Wilfred G. E. Watson (Sheffield: Sheffield Academic Press, 1990). See also, Eep Talstra, "A Hierarchy of Clauses in Biblical Hebrew Narrative," in Narrative Syntax and the Hebrew Bible: Papers of the Tilburg Conference 1996, ed. Ellen Van Wolde, BIS 29 (Brill: Leiden, 1997), 85-118; Roy L. Heller, Narrative Structure and Discourse Constellations: An Analysis of Clause Function in Biblical Hebrew Prose, HSS (Winona Lake: Eisenbrauns, 2004), 428-482. On the use of wayyiqtol for "tracing the thread of discourse" see also IBHS 33.2.c7. The x-qatal forms describe narrative.

8 Timothy R. Ashley, The Book of Numbers (Grand Rapids: Eerdmans, 1993), 190, argues for two travel sections: 10:11-12:16 and 20:1-22:1. So also Gordon J. Wenham, Numbers (Leicester: InterVarsity, 1981), 103. Cross, Canaanite Myth, 308, acknowledges that the formulaic headings introduce sections which vary greatly in size: "they are quite short until one reaches the wilderness of Sinai where the complex of Epic and especially Priestly legislation runs from Exod 19:1 to Num 10:10. Other long sections include Israel's stay in the Wilderness of Paran (Numbers 10:11-19:22) and in the Plains of Moab (Numbers 22:1-36:13 plus Deuteronomy 34)." 
516 Leder, "From the Mountain of YHWH," OTE 29/3 (2016): 513-534

(Exod 19:3-Num 10:10) breaks the plot of the putative single journey ${ }^{9}$ from Egypt to Moab into pre- and post-Sinai sections, to argue that the first itinerary cluster in Numbers (10:11-36) forms the conclusion to Num 1:1-10:36. In order to do so I will compare and contrast the itinerary clusters in Exodus and Numbers, then argue that Numbers depicts two itinerary clusters (10:11-36; 20:2222:1), the first of which, in conclusion of Num 10:1-10:10, depicts the resumption of YHWH'S victory march which began on Passover night with the stated goal in Num 10:33, "to seek rest for them (i.e., Israel)." As the conclusion to Num 10:1-10:10, and distinct from the second, Num 10:11-36 also depicts the first generation as fully compliant with divine and Mosaic instruction.

\section{B THE ITINERARIES OF EXODUS AND NUMBERS: A COMPARISON}

Israel's journey ${ }^{10}$ begins on a specific date, Passover night (Exod 12:29-36) and ends during the third month after leaving Egypt, "on this very day" (Exod 19:12 ). The only other date marking the journey, in Exod 16:1, also measures the departure in terms of leaving Egypt: "... the fifteenth day of the second month." The Exodus itinerary takes Israel from one specific place, Rameses in Egypt (Exod 12:37), to another, the desert of Sinai, “... in front of the mountain" (Exod 19:2). Thus Israel's journey consists of a larger narrative sequence within which the "itinerary markers," typically wayyiqtol of נסע, signal narra-

9 The journey itself is secondary to the plot: the theophany at Sinai whose instruction replaces that of Egypt and Canaan (Lev 18:1-5). Thus, while in a general sense Sinai is one stage in the journey, the canonical Pentateuch depicts one pre-Sinai and two post-Sinai itinerary narratives.

10 Exodus uses eight wayyiqtol forms (Exod 12:17; 13:20;14:19²; 15:22; 16:1; 17:1; 19:2) to describe the journey to Sinai. The distinction between the itinerary verbs in their wayyiqtol and $w^{e}$ qatal narrative sequence (Niccacci, Syntax, $\S \S 7,38-48$ ) is important because the wayyiqtol is the primary narrative form and the qatal provides background information. The travel narrative verb is נסע. Roskop, Wilderness Itineraries, 177, holds that בוא is not characteristic of the itinerary genre; it articulates movement to a place. Artus, Etudes, 218-219, takes it as an itinerary notice, translating as "entera" or "arrivèrent" (Artus, Etudes, 51, 204). If נסע is "to decamp" (Won W. Lee, Punishment and Forgiveness in Israel's Migratory Campaign [Grand Rapids: Eerdmans, 2003], 90), then בוא would be "to encamp." 
tive continuation (e.g., 14:19) ${ }^{11}$ or initiate sections of the journey $(12: 37 ; 13: 20$; $15: 22 ; 16: 1 ; 17: 1 ; 19: 2) .{ }^{12}$ The markers of the Exodus itinerary are:

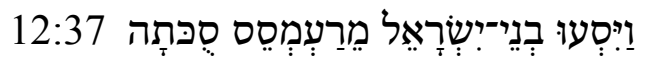

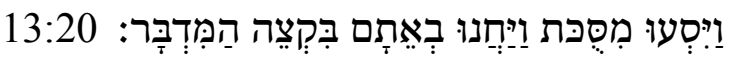

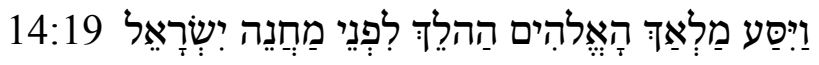

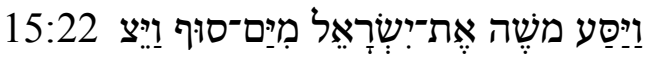

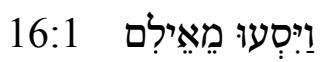

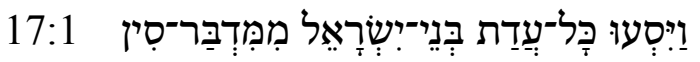

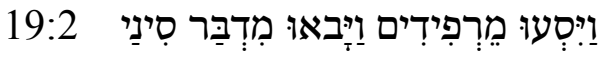

The first itinerary notice in Numbers also begins with a specific date $(10: 12)$ and is understood to take Israel from one geographic location, the desert of Sinai to Paran, all in the same verse (Num 10:12). However, the subject of the itinerary markers shifts from Israel to the ark in 10:34-36 where frequentative verbs describe the journey led by the ark. The narrative does not give a specific date for arrival in Paran nor the locations in Num 11:1-35. The journey with Israel as subject of the travel verb begins again, at Paran (20:22; cf. 20:1 and 10:12), and ends in Moab (22:1). Thus Israel's journeys in Numbers are also embedded in a larger narrative sequence within which the "itinerary markers," typically wayyiqtol of נסע, signal narrative continuation or initiate sections of the journey $(10: 12,13,14,29,33$ and $20: 22 ; 21: 4,10,11 ; 22: 1)$ ${ }^{13}$ between Sinai and Moab. ${ }^{14}$

11 Exod 14:10 uses a present participle of נסע to depict the Egyptians; 14:15 a wayyiqtol $3 \mathrm{~m} \mathrm{pl}$ in the jussive. The latter applies to Israel. It is the Angel of the Lord, however, who is depicted as traveling before Egypt in 14:19, but when they do enter the sea the narrative uses בוא (14:29) for when they move on dry ground. If we limit the "itinerary markers" to Israel and in the wayyiqtol form, there are six, as Cross suggests.

12 Wayyiqtol of נסע: Exod 12:37; 13:20;15:22 [+ בוא ] 16:1; 17:1; 19:2 [+ of Israel's travels; w'qatal in Exod 14:15 [ויסעו, an instruction] followed by בואו [בוא, entry into sea on dry ground], 19:2 [ויסע] descriptive of the movement of the angel of the Lord and the cloud. These six notices are balanced by six in Num $(10: 12 ; 20: 1 ; 20: 22$; $21: 10-11 ; 22: 1 ; 25: 1)$ according to Erich Zenger, et al., Einleitung in das Alte Testament, Band 1,1 (Stuttgart: Kohlhammer, 1995), 37.

13 Only the verb נסע as per the description of the entire journey in Num 33:1-2 as מסע (excluding the wayyiqtol of בוא in Num 20:1). Even Israel's יצים are described according to their מסים (33:2), excluding the forms in 10:14, 28 because these describe the order of the march. The function of the qatal forms in 11:35; 12:16; 
518 Leder, "From the Mountain of YHWH," OTE 29/3 (2016): 513-534

Rolf Knierim considers the "itinerary chain" in Numbers to link the initial Sinai and the final plains of Moab geographies because Israel's desert journeys in Num 10:11-36:13 depict an execution of Israel's previous preparations for the journey at Sinai (Num 1:1-10:10). ${ }^{15}$ That is, the Numbers itinerary can be taken to begin at Mt. Sinai in the desert of the same name (Num 10:12, 33; cf. Exod 19:2), to stop in the desert of Paran (Num 12:13), and then from Kadesh $^{16}$ to Mt. Hor and Aaron's death (Num 20:22), and from there around Edom and the incident of the bronze serpent-without naming the location of the serpent event (Num 21:4; [between Hormah and Oboth]) - to the Arnon River, the border of Moab (Num 21:10,11), and from there to the plains of Moab, across from Jericho (Num 22:1). ${ }^{17}$

However, Numbers uses not one, but two itinerary narratives to depict Israel's journey from Sinai to Moab, each of which characterizes the journey differently. Thus the itinerary narrative of 10:11-36 begins on a specific date (10:11), mentions its endpoint in 10:12 and then, in a compressed manner not unlike Num 33, describes the tribes in their military marching order, without

$21: 12,13$ (excluding the forms in 10:17, 18, 21, 22, 25, per above) will be discussed below. The verb also appears in qal inf. in 10:34.35; as a qal ptc. in 10:9, 33, and an imperative in 14:25. Non-wayyiqtol uses of נסע in Num 11 and 12 will be discussed below. The difference between the subsequent events is that Miriam dies in Kadesh and Aaron at Mt. Hor. On the use of the travel verbs discussed in itinerary scholarship, see also Dozeman, "Priestly," 259 note 7; and Coats, "Wilderness," 136-138.

14 Because these itineraries mark journeys begun and ended within the narrative, they cannot structure the entire books of Exodus or Numbers. Contra Rolf Knierim, "The Book of Numbers," in The Task of Old Testament Theology: Method and Cases, ed. Rolf Knierim (Grand Rapids: Eerdmans, 1995), 383. Nor does it supply the overarching theme, as suggested, for example, by Katharine D. Sakenfeld, Numbers: Journeying with God (Grand Rapids: Eerdmans, 1995), 1-2.

15 Knierim, "Numbers," 380-388: preparation (chs. 1-10:10) and execution (chs. 10:11-36); Lee, Punishment, 95-98; Won W. Lee, “The Concept of the Wilderness Journey in the Pentateuch," in Israel in the Wilderness: Interpretation of the Biblical Narratives in Jewish and Christian Traditions, ed. Kenneth E. Pomykala (Leiden: Brill, 2008), 6-16.

16 Wenham (Numbers, 17 and $115 \mathrm{n}$ 1) lists Israel as arriving in Kadesh in Num 13:2, but explains this identification subsequently. But that ignores the text as it is in favor of a harmonizing reading. Juxtaposed to 12:16 Israel is in the desert of Sin. Israel's arrival at Kadesh is noted at 20:1, with the verb בוא; there is no notice of travel to Kadesh with נסע. That the itinerary verb is seems clear from 20:22 where נסע depicts the travel and arrival. The difference in forms makes the reader stop and reflect.

17 Num 10:11-22:1 is taken as the larger narrative unit by Wenham, Numbers, 103; Jacob Milgrom, Numbers, JPS, Torah Comm. (Philadelphia: Jewish Publication Society, 1990), 75 . 
mentioning specific events or encampments. ${ }^{18}$ A summarizing inset hymn closes this section. The second itinerary narrative (20:22-22:1) begins when Israel departs from Kadesh (20:22), and narrates a variety of events that take place during this journey (Aaron's death, the bronze serpent, the problem with Edom and the victories over Arad, Sihon and $\mathrm{Og}$ ), and ends on the plains of Moab (22:1). Where Num 10:11-36 depicts the first generation's total compliance with Moses' instructions (10:13), the second, more like the Exodus itinerary, discloses the first generation's complaints, their deadly consequences, military victories, and rebellion against divinely appointed leadership. The two itinerary narratives are separated by a long non-travel narrative characterized by Israel's complaints, non-compliance, death, and divine instruction.

The five wayyiqtol forms ${ }^{19}$ of the itinerary verb נסע in the first narrative describe a journey which begins in the desert of Sinai (mount of YHWH, 10:33), but does not encamp anywhere. Rather, the depiction ends with the ark continuing to seek rest for Israel (מנוחה, 10:33b).

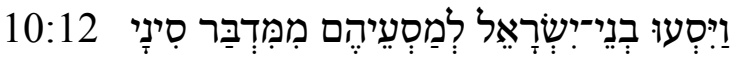

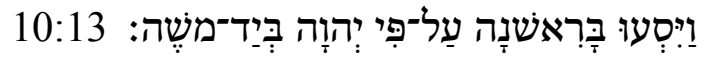

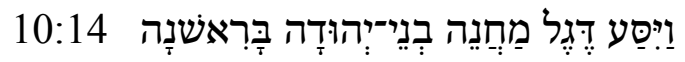

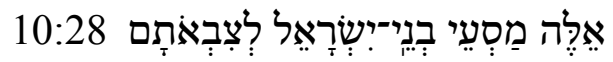

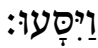

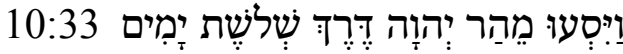

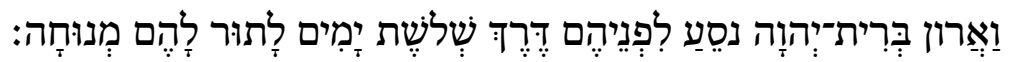

Although 10:12 identifies Paran as Israel's destination, the following itinerary itself betrays no interest in encampments, only YHWH dwells in Paran (שנן , שכן). 10:12; for Israel, in 12:16ereafter, specific geographical locations begin in 11:1-3, and arrivals, with the verb בוא in the wayyiqtol narrative sequence, in 20:22. Furthermore, it is the ark's journeying and coming to rest (present participle, 10:33; infinitive construct, 10:33-36, of נוח), without mentioning a location, that appears to form a conclusion to this desert march account. In the received shape the ark, not Hobab, ${ }^{20}$ spearheads Israel's desert

18 Excluding the insertion of the Hobab pericope (11:29-32).

19 On these forms see footnote 12.

20 On the text's silence about Hobab's reply to Moses' invitation, Milgrom, Numbers, 80, writes: "[The absence of a reply] is more likely due to the conviction that Israel's safe journey through the wilderness was due to the guidance of the Ark, not of Hobab." So also Horst Seebass, Numeri 10,11-22,1, vol. 2 of Numeri, BKAT (Neukirchen: Neukirchener, 2003), 7, 17 ("Näherhin empfindet man aber durchweg, 
journey. Because it is the goal of the ark to find a place of rest ${ }^{21}$ for Israel ( לָּ (דָלֶם מְנוּחָה 1:1-10:36 ends on that positive note.

The five wayyiqtol forms of the itinerary verb נסע clustered in Num 20:22-22:1 describe a journey from Kadesh to the plains of Moab.

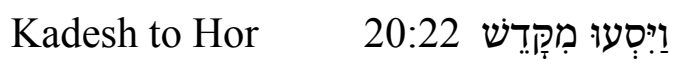

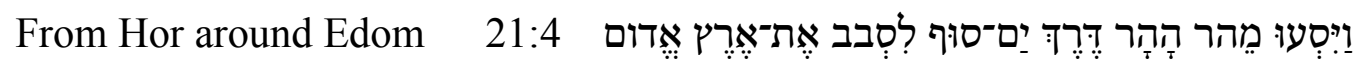

To Oboth

From Oboth to Iye Abarim

To Moab

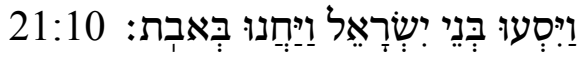

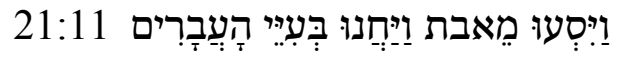

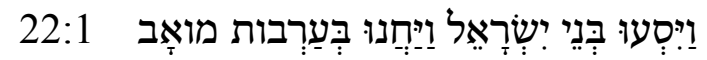

Unlike the first cluster, the second is embedded in a narrative of complaints and disobedience. Numbers 11:1-3 names the place where Israel's complaints begin (Taberah; Kibroth-hattaavah and Hazeroth in 11:35), but not when they arrived at this location. Indeed, the new theme of complaint ${ }^{22}$ subordinates the travel interest, until it emerges again in 20:22, after a long section of divine instruction (18-19) and the events at Kadesh in 20:1-21: Moses' and Aaron's disobedience and Edom's refusal to allow Israel to pass through its territory. When the travel interest re-emerges, it begins with Aaron's death (thereby casting a shadow over this journey) and rebellion against divine and Mosaic authority, and brief descriptions of military victories. These narrated events in the second cluster depict a desert journey similar to that of Exodus (complaints, victory over Amalek), but completely unlike that of Num 10. Furthermore, like the Exodus itinerary, which ends at Sinai where Israel is fully instructed and commits apostasy, the second Numbers itinerary ends on the plains of Moab, where YHWH defeats Balak but Moab successfully seduces Israel into apostasy. Finally, where the ark's seeking rest (מנוחה) caps the first

dass 33b Hobabs mögliche Funktion zu ersetzen scheint. Denn מנוחה bedeutet nicht ganz dasselble wie סחנה, sondern lässt [zumal in Verbindung mit 35f] Sicherheit vor den Feinden assoziieren Jes 66,1; Ps 95,11; Rt 1,9; Dtn 12,9; 1 Kön 8,56 [...]... Daher umgreift die Funktion der Lade die Hobabs.")

21 The noun מנוחה may "connote a permanent, secure habitation" writes, Baruch Levine, Numbers 1-20, AB (New York: Doubleday, 1993), 317. He fails, however, to cite Deut 28:65 (which evokes Gen 8:8).

22 Dennis T. Olson, The Death of the Old and the Birth of the New: The Framework of the Book of Numbers and the Pentateuch (Chico: Scholars Press, 1985), 122; Artus, Etudes, 25, argues for "[une] cesure entre $\mathrm{Nb} 10,36$ et $\mathrm{Nb}$ 10,11-36," because "[b]rutalment, en $\mathrm{Nb} 11,1$, la tonalité et le thème du récit changent, avec un episode de protestation du peuple." The third ויהי marker also links Num 1-10 and Num 11-36, thereby providing a syntactic continuity. The thematic change in 11:1 expresses discontinuity. 
Numbers travel account, Israel's disastrous affair with the Baal of Peor caps the second.

This comparison of the itinerary narratives in Exodus and Numbers suggests that the first Numbers cluster distinguishes itself from the other two because it is untroubled during its journey, does not include any encampments, and that unlike Sinai and Moab-where Israel committed apostasy (Exod 3233; Num 22:2-24) - it is defined by the ark's seeking a resting place for the people.

\section{Exodus:}

1. From Egypt (Rameses)

a. troubled desert itinerary (murmuring vs. God and Moses)

b. to Sinai:

i. divine instruction (victory over Egypt, cf. Exod 29:45-46

ii. Aaron and Israel's apostasy

\section{Numbers:}

1. From Sinai (compliance with Moses' instruction)

a. untroubled desert itinerary

b. to the rest the ark seeks for Israel

2. From Kadesh (non-compliance)

a. troubled desert itinerary (murmuring vs. God and Moses)

b. to Moab:

i. YHWH'S victory over Balak

ii. Baal of Peor's seduction of Israel

In what follows I will examine in greater detail the structure and character of the itinerary in Num 10:11-36, to argue that it concludes the first major narrative section of Numbers, that it differs in several ways from the second cluster, and that in doing so it depicts the obverse of the Janus face of the first generation: totally compliant with divine instruction. ${ }^{23}$

\section{THE ITINERARY CLUSTER OF NUMBERS 10:11-36}

Based on the understanding that 10:11-12 begins Israel's journey from Sinai to Moab, it is commonly argued that 10:11 begins the second major unit of the book of Numbers. Wenham, for example, argues that geography organizes the structure of Numbers because it is composed of "large cycles in which three

23 On Num 1-10 as a Janus face, see Christian Frevel and Erich Zenger, "Die Bücher Levitikus und Numeri als Teile der Pentateuchkomposition," in The Books of Leviticus and Numbers, ed. Thomas Römer (Louvain: Peeters, 2008), 61-68. 
important eras of revelation, at Sinai, Kadesh, and in the plains of Moab, are separated by two bridge passages describing the journeys from Sinai to Kadesh, and from Kadesh to the plains of Moab." The first journey, depicted in 10:12, apparently stops in Taberah, Kibroth-hattaavah and Hazeroth; it also "... begins exactly as prescribed in the previous chapters." ${ }^{24}$ But that Kadesh is the arrival point of the first journey can only be supplied from Num 13:26; 20:1; and 10:12 only mentions the desert of Paran, not a specific location within it. Ashley argues similarly, but acknowledges that "[ $\mathrm{t}]$ he identification of geographical sites is difficult because often no trace of a biblical name remains on a site." ${ }^{25}$ Knierim and Lee present a different argument: the itineraries shape the entire book of Numbers because they belong to "a conceptuality underneath the text," 26 a subsurface conceptual structure composed of a "preparation" for (Num 1:1-10:10) and an "execution" (Num 10:11-36:13) of the march.

Such readings falter on several accounts. First, why supply Kadesh as the goal of the first itinerary when 10:12 defines it as the general location of the desert of Paran, and that it is YHWH who dwells there, not Israel? ${ }^{27}$ Elsewhere the text is specific about locations $(11: 3,35 ; 12: 16)$. Moreover, why should the lack of a specific location be a textual problem? Why exclude the possibility that 10:11-36, unlike the second cluster and Num 33, intentionally omits specific locations? Second, 11:1-3 is specific about a location, as are 11:35 and $12: 16$, but these locations and the notations of setting out or arrival are subordinated to the narrative of Israel's complaint and lack of compliance with divine instruction. Along with the vague date in Num 20:1 (like that of Exod 19:1-2), understood to introduce an event at the end of the 40 years journey, these references suggest that dischronology is part of Numbers' narrative strategy. Furthermore, Wenham's "bridge passages" do not, as a matter of textual fact, describe the journey as do 10:12-36 and 20:22-22:1, but focus on events or divine instruction. References to journeys and locations in these passages are subordinate to the subject matter of complaint, non-compliance, or divine instruction. Third, using a "subsurface conceptuality" to determine the role of the itineraries, as do Knierim and Lee, introduces a subjective element into a plain reading of the text's surface, that is, a subsurface reading of the text.

24 Wenham, Numbers, 15, 104.

25 Ashley, Numbers, 193.

26 Knierim, "Numbers," 380-388; Lee, Punishment, 95. Num 10:11-36 constitutes the first unit in the journey of execution, Rolf P. Knierim and George W. Coats, Numbers, FOTL 4 (Grand Rapids: Eerdmans, 2005), 148-152.

27 "Verse 12 summarizes several stations, since the Israelites stop at Kibroth-hattaavah and Hazzeroth before they reach the wilderness of Paran $(11: 35 ; 12: 16)$. The likelihood, however, is that the wilderness of Paran is not a station but is the general name for the northern half of the Sinai Peninsula, ... "So Milgrom, Numbers, 76. Emphasis added. 
Furthermore, arguing that Num 10:11-36:13 is the "execution" to 1:1-10:10's "preparation" (Num 10:11-36:13) ignores the narrative move to the second generation in Num 26-36. This generation, with the exception of Moses in 27:22 (with respect to Joshua) and the daughters of Zelophehad in 36:10, is not at all described as compliant with divine instruction, as is the first, with phrases such as: "The Israelites did all this just as the Lord commanded Moses" (1:54).

To answer these concerns I turn to a brief discussion of Num 1:1-10:36 to argue that Num 1:1-10:10 is itself an instruction-compliance sequence with respect to the camp, and that Israel's journey from Sinai, beginning with Num 10:11, does not depict Israel's execution of 1:1-10:10's instructions, but is itself an instruction-compliance narrative which depicts the first generation's compliant travel in following the ark to its various resting places. ${ }^{28}$

\section{Numbers 10:11-10:36: the Continuation of YHWH's Victory March}

Numbers 1:1-10:10 does not depict, as Knierim and Lee argue, Israel's preparations for subsequent execution on the journey, but a series of divine instructions from the Tent of Meeting (Num 1:1 [ה [הל מועד]), introduced by a form of "and the Lord spoke" $(2: 1 ; 3: 6,14,44 ; 4: 1,17,21 ; 5: 1,6,11 ; 6: 1,22 ; 8: 1,5 ; 9: 1,9$; $10: 1$ ), intended to organize the conduct of life in the camp in YHWH's presence (Num 5:3). Numbers depicts Israel complying with these instructions-"The Israelites did just as the Lord commanded" $(1: 54 ; 2: 34 ; 3: 51 ; 4: 49 ; 5: 4 ; 7: 1-3$; $8: 4,20,22 ; 9: 5,15-23$ ) - before the march begins, in the same location depicted by Exod 40:34-Lev 1:1, thus, still at the foot of Mt. Sinai (Num 1:1 [אהל מועד]; cf. 10:33). Numbers 1:1-10:10 then, is not a preparation for a subsequent execution; the execution of YHWH's instructions is depicted as already accomplished. If this is so, then the itinerary beginning in 10:11 cannot be understood as an execution that begins the second major part of Numbers. Rather, it suggests that the first generation who is encamped at Sinai, now fully instructed and compliant, continues the military victory march begun on the night of the tenth plague (Exod 12:37). The goal now is defined in terms of the ark's seeking rest (מנוחה) for Israel, not in terms of specific encampments. According to Zenger and Frevel, this interaction of Num 1:1-10:10 with 10:11-36 reveals the Janus-face function of Num 1-10, that is, these chapters are linked literarily to Sinai and look forward to the journey. ${ }^{29}$ Several textual features support the claim that the first itinerary cluster may be properly distinguished from the first, and that it is the proper conclusion of Num 1:1-10:36.

28 The only other travel verbs close to preparations or instructions for the march are found in Num 10:5-6. But the opening words instruct Israel in the cultic character, the trumpets, of the journey. Other uses of נסע are iterative/habitual (Num 9) or descriptive of the order of the march (Num 2).

29 Zenger and Frevel, "Levitikus und Numeri," 67-68. 
524 Leder, "From the Mountain of YHWH," OTE 29/3 (2016): 513-534

First, Num 9:15-23; 10:11-12 and 34 depict Israel's movements, under the guidance of the cloud, from the desert of Sinai (the place they entered a year before [Exod 19:2]). There are no encampments. ${ }^{30}$ From Num 11 forward the wayyiqtol itinerary notices do not include references to the guidance of the cloud; the cloud appears only in contexts of judgment. ${ }^{31}$ The association of the cloud with Israel's journeys in Num 10:11-36 and lack thereof with itinerary notices after Num 11, distinguishes the first from the second itinerary cluster.

Second, Num 10:11 initiates the first itinerary with a ויהי and temporal designation, typical of a new literary unit, followed by a travel narrative structured by three wayyiqtols (ויסעו 10:12,13,14), a summary statement (אלה מסעי, 28a, "these are Israel's travels"), followed by a wayyiqtol (איסעו 28b) reiterating the travel. After the Hobab insertion, a resumptive wayyiqtol (ויסעו, $33 a)^{32}$ continues the travel narrative. Within the wayyiqtol shaped travel narrative, subordinate verbal sequences (x-qatal verbs in 10:17, 18, 21, 22, 25), describe the nature of the journey. ${ }^{33}$ The tight, formulaic character-the repetition of "the banner of the camp of ... set out, over the battalion of ..., and over the battalion of ..., and over the battalion of ..." (14-16; 18-20; 22$24 ; 25-27)$, the four banners $(10: 14,18,22,25)$ that lead Israel's battalions in YHWH's presence $(10: 11,12,34)$, and the repetition of the noun batallion (צבא, 17x; which forms an inclusion with Num. 1 [where צבא 16x]), all distinguish this cluster. Furthermore, because neither the noun nor the verb of צבא occurs

30 Jacob Milgrom, Leviticus 1-16: A New Translation with Introduction and Commentary (New York: Doubleday, 1991), 70, writes that "[t]he lengthy priestly legislation beginning with Leviticus 1 is now concluded by an elaboration of the passage that ends the book of Exodus (40:36-38), thereby forming an inclusion around the entire section (Exod. 19-Num. 9). Thus Israel's movement in the wilderness (Exod. 15-18), interrupted by the Sinai legislation (Exod. 19-Num. 9), is now resumed." But the journey cannot be understood to begin in Num 9. Milgrom himself acknowledges that all the verbs are imperfect frequentatives (except for verbs in 15a and 23), which, like those in Exod 40:36-38 refer to future continuous action, very much like the movement depicted in Num 10:35-36. The depictions of Israel's journeys in Exod 40 and Num 9:15-23 and 10:35-36 appear to cover all travel, with the common theme of the cloud giving guidance in the desert.

31 This is the case whether the itinerary verbs are qatal or wayyiqtol. The reference to the cloud and the journeys in Num 14:14, occurs in Moses' plea that YHWH withholds his judgment on Israel for failure to enter the land.

32 IBHS 33.2d13-15 (summarizing); Ashley, Numbers, 198, argues that v. 33 "looks back to the same words in the summary statement of v. 12 and bring[s] the description of the departure to completion." George B. Gray, A Critical and Exegetical Commentary on Numbers (Edinburgh: T\&T Clark, 1903), 91, argues that the verbs in vv. 1727 are frequentative, "indicating general practice on a series of marches."

33 On the subordination of these sequences, see footnote 10. 
in chs. $11-25,{ }^{34}$ the second itinerary cluster $(20: 22-22: 1)$ does not describe the people as the battalions of the Lord.

Third, where the second itinerary cluster includes specific encampments, Num 10:12-24 depicts no halts in the journey; Num 10:33-34 describes the ark's guidance with forms indicating continuing travel (cf. Exod 40:36-38). ${ }^{35}$ Numbers 10 twice depicts this open ended journey from the mountain of the Lord as taking three days. Both Ashley and Wenham take the first occurrence literally, namely, it took three days to arrive at the first encampment. ${ }^{36} \mathrm{~A}$ literal three days comports with the understanding that the first itinerary includes chs. 11 and 12, with Num 12:16 indicating Israel's arrival at Paran. Ashley, however, understands the repetition of the phrase to mean "the duration of the journey during the whole of which the ark went before (לפני) the people," without explaining the shift in meaning. ${ }^{37}$ This reading assumes a switch from a literal to a metaphorical meaning within two clauses, although some argue for excision of the second occurrence. ${ }^{38}$ Roland Gradwohl, however, argues that the phrase "a three day journey" does not define an exact span of time, but indicates the goal of an event being depicted, often expressed with the phrase "the third day," as in the appearance of the divine in Exod 19:11, 16, on the third day. ${ }^{39}$ This would convert the phrase from a depiction of a literal three days to a literary convention. If this is the case in Num 10:33, that would change the length of the journey from a literal three days to one of indicating an important event, a goal not attained in Numbers because the ark keeps moving (vv. 34-36). ${ }^{40}$ A short look at the text will help to identify this event:

34 Elsewhere in Numbers the noun צבא occurs in 26:2; $31^{13 x} ; 32: 27$; and 33:1. The verb occurs in $4: 23 ; 8: 24 ; 31: 7$; and 31:42. Commenting on 10:35a, Martin Noth (Numbers [Philadelphia: Westminster, 1968], 79) writes, “... this is a setting out not on further travels but to battle with the enemy." Emphasis added.

35 Noth, Numbers, 75.

36 Probably Kibroth-hattaavah, according to Ashley, Numbers, 198, n. 27; the first stage of the journey (Wenham, Numbers, 105).

37 Ashley, Numbers, 199.

38 Ashley, Numbers, 198, writes: "It is tempting to excise the phrase as an inadvertent repetition that entered the text from the first part of the verse, but there is little textual evidence for such a phrase." Such an excision is recommended by BHS and Noth, Numbers, 78.

39 Roland Gradwohl, "Drei Tage und der dritte Tag," VT 47/3 (1997): 376. See also Marius G. Swanepoel, "Die 'drie dae' motief in die Ou Testament (BHS)," NGTT 32 (1991): 541-551, who comes close to Gradwohl's position (Swanepoel, "Motief," 548-49), but finally concludes that the three day motif represents hope (Swanepoel, "Motief," 550).

40 After Num 11 the ark appears only once: 14:44 states that the ark did not leave the camp (14:44) to engage the peoples of the land. 


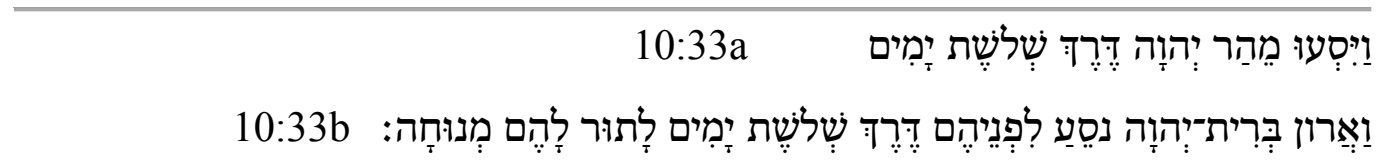

Numbers 10:33a depicts Israel's journey from "the mountain of YHWH," not the desert of Sinai, ${ }^{41}$ with a typical wayyiqtol construction of 10:33a (evoking those in 10:12,13,14). This sequence is not followed by an expected wayyiqtol sequence, but by a circumstantial disjunctive clause which describes the nature of Israel's journey: "Now, it was the ark of the covenant of YHWH which was journeying in front of them for three days." This clause introduces two changes. First, the subject of the verb shifts from the people to the ark. Second, the purpose of the ark's journeying is added: "to find rest for them" ( לָתוּר לֶָהָם

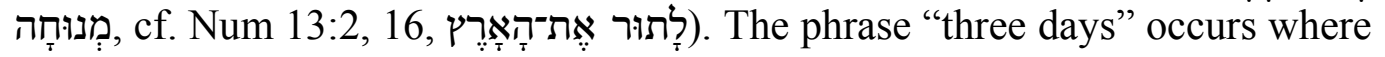
one expects to find a depiction of an encampment (as in Num 21:10, 11 and $22: 1$ ); in 10:33a it appears as part of Israel's journey, and in 10:33b to indicate that the ark leads Israel in its journey. If Gradwohl is right about the function of the "three days," then the event being depicted can only be the ark's goal of finding rest for Israel, a goal not attained in Numbers, only continually sought as the ark keeps moving (vv. 34-36). ${ }^{42}$ The "three day" journey of Israel-ledby-the-ark from the mountain of YHWH does not take Israel to Taberah or Kibroth-hattaavah, for there is no such notice, ${ }^{43}$ but launches them on a journey that will not end until the ark itself reaches Zion (1 Kgs 8:6). If it is the ark's intent to find rest for God's people, and that this intent anticipates Solomon's

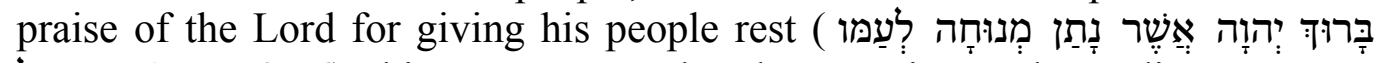
ישֶׁרֵֵאל 1 Kgs 8:56), this may suggest that the narrative evokes a direct connection to a compliant ${ }^{44}$ first generation that leaves the mountain of the YHWH and which finds its rest in Zion; the non-compliant first generation does not depart

41 The different points of departure in 10:12 and 10:33 may be a distribution of phrases that occur together in Exod 19:2, where Israel arrives in the desert of Sinai, opposite "the" mountain. "The mountain" can only be the mountain where God revealed himself to Moses, an abbreviated form of "the mountain of YHWH." If this so, the distribution of these locations forms an inclusion for the first itinerary cluster.

42 The repetition of the phrase facilitates a shift in subject of the travel verb: from Israel in 10:33a to the ark in 10:33b. The effect removes Israel from defining its destination and emphasizes again that the journey is YHWH's victory march.

43 Commentators assume such an arrival on the basis of Num 11:1 and 4. Thus Gray, Numbers, 96; Ashley, Numbers, 193; Wenham, Numbers, 104-105.

44 Knierim, Numbers, 148, entitles 10:11-36 as a "Legend of the Ideal Beginning of the Epiphanic Campaign from the Wilderness of Sinai to the Wilderness of Paran," Note that Knierim writes the "ideal beginning," not the ideal generation. 
from the desert of Sinai nor from the mountain of YHWH; and, because it never leaves Moab, ${ }^{45}$ it remains in the desert (cf. Ezek 20:35).

A second ויהי (35) introduces Moses' repeated ${ }^{46}$ invocation that YHWH rise to battle his enemies, thereby emphasizing that this journey is YHWH's military march (cf. Num 1). As do many inset psalms, this small unit closes the pericope begun in 10:11 by bringing "the narrative to a climactic finale," in military terms. Numbers 10:35-36's depiction of the journey is similar to that

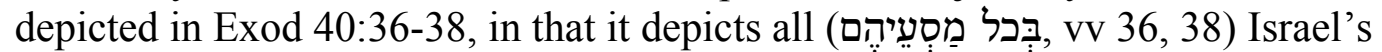
journeys in terms of the lifting of the cloud (cf. Num 10:12, 34), but without mentioning any encampments. And, as Exod 40:36-38 concludes the entire Exodus narrative, ${ }^{48}$ so Num 10:35-36 concludes the first major narrative unit of Numbers. The major difference between the two is that Num 10:35-36 focuses the journey from the mountain of YHWH on the ark's finding rest (מנוחה) for God's people.

45 The ark's military movements are subsequently depicted in Josh 3-4 and 6, and in 1 Sam 4-6:1. See Samuel Terrien, The Elusive Presence: The Heart of Biblical Theology (San Francisco: Harper \& Row, 1978), 162-175.

46 The verb ויאמר is frequentative, Gray, Numbers, 97.

47 See Milgrom, Numbers, 375-376, on the inverted nuns that separate these verses; James W. Watts, Psalm and Story: Inset Hymns in Hebrew Narrative, JSOTSup 139 (Sheffield: Sheffield Academic Press, 1992), 174, states that Num 11:35-36 belongs to those short poems that "seem to be neither related to the plot, nor in a structurally climactic position." The poem accompanies the ark's movement, "its regular performance indicated by [the] wyhy" clause. And, "the poem appears at the end of Numbers 10 because the chapter reports the departure from Sinai and thus the first time that Israel's movements have been accompanied by the ark." But three temporal clauses introduced by ויהי suggest three macro-syntactical sections (IBHS 3.3.4d; 13.5.1e), signifying the beginning of different units; the shift of theme in 11:1 suggests that the poem does signal the end of a unit. If not climactic in the sense of Exod 15:1-18, it is definitive for the entire march (as is Exod 15:19-21): it is YHWH's victory march at the head of a camp organized according to the instructions preceding the march. Ashley, Numbers, 198, suggests that Num 10:35-36 concludes the chapter as does Num 6:22-27. Roskop, Wilderness Itineraries, does not examine this narrative sequence, nor the narrative function of the poetic insertion. Similar to Exod 40:36-38, an insertion which breaks the narrative continuity between Exod 40:35 and Lev 1:1, Num 10:35-36 also closes the narrative and characterizes Israel's future movements (cf. Num 9:15), without formally being a part of an itinerary.

48 Without this unit Lev 1:1 would continue the narrative from Exod 40:34 with typical wayyiqtol forms. On the literary aspect of this connection, see Rolf Rendtorff, Leviticus, vol. 3.1 (NeuKirchen-Vluyn: Neukirchener Verlag, 1985), 23. 


\section{2 מנוחה for God's People}

1 Kings 8:56's reference to מנוחה is often recognized as "the culmination of the desert wandering and conquest of Palestine, ${ }^{, 49}$ the fulfillment of a promise given in Deuteronomy $(12: 9-10 ; 25: 19),{ }^{50}$ but seldom is it linked to its appearance in Num 10. ${ }^{51}$ Von Rad writes that the "echoes (of נוח) are heard throughout that massive historical work to which we apply the designation 'deuteronomic." " ${ }^{52}$ Although Noth insisted that the Deuteronomistic History began with Deut 1, Christoph Levin suggests that because Deut 1-3 repeats elements from Num 26-32, "the purpose of [Deuteronomy's] new beginning was to fit the Deuteronomic law into the sequence of historical events." ${ }^{53}$ This suggestion warrants the conclusion that in its present pentateuchal location Deuteronomy addresses the second generation as defined by Num 26-32; and that its themes address the second generation's self-understanding as it marks time on the plains of Moab.

If this is so, then Num 10:33-36's use of מוח מנוחה may be understood to anticipate Deuteronomy's interest in rest (first noted in 3:20), implied in Num 10:33-36, and subsequently developed in Joshua (enemies: 1:15; 21:44; $22: 4 ; 23: 1$; but also, [the feet of the priests who are carrying] the ark: $3: 13$; stones: 4:3, 8, 20; and, Rahab: 6:23) ${ }^{54}$ Furthermore, the association of the ark of the covenant with Israel's rest in Numbers, subsequently in Joshua and especially in $1 \mathrm{Kgs} 8: 56$, is suggestive of a movement towards rest, which begins with the first generation's move from the mountain of YHWH (Num 10:12

49 Rest in $1 \mathrm{Kgs}$ 8:56 represents "the culmination of the desert wandering and conquest of Palestine in the Heilsgeschichte, and as such is the subject of the 'Mosaic' Deuteronomy." John Gray, I \& II Kings (Philadelphia: Westminster, 1963), 214. Similarly, Hendrik A. Brongers, I Koningen (POut; Nijkerk: G. F. Callenbach, 1963), 100; and Martin J. Mulder, 1 Kings 1-11, vol. 1.1 of Kings, HCOT (Louvain: Peeters, 1989), 446.

50 Gerhard von Rad, "There Remains Still a Rest for the People of God: An Investigation of a Biblical Conception," in The Problem of the Hexateuch and other Essays, ed. Gerhard von Rad, trans. E. W. Trueman Dicken (London: SCM, 1966), 94-97.

51 Among the texts typically appearing in discussions of מנוחה, Seebass, Numeri 2, 17, includes $1 \mathrm{Kgs}$ 8:56 when discussing נוח and Num 10:35-36.

52 Von Rad, "There Remains," 97.

53 Christoph Levin, "On the Cohesion and Separation of Books with the Enneateuch," in Pentateuch, Hexateuch, or Enneateuch? Identifying Literary Works in Genesis through Kings, ed. Thomas B. Dozeman, Thomas Römer, and Konrad Schmid (Atlanta: Society of Biblical Literature, 2011), 150, 152.

54 For a discussion of these texts, see Arie C. Leder, "Hearing Esther after Joshua: Rest in the Exile and the Diaspora," in The Book of Joshua and the Land of Israel, ed. Ed Noort, BETL 250 (Louvain: Peeters, 2012), 268-271. 
[Sinai], 33) and culminates in the ark's entering Zion's holy of holies (1 Kings 8:6). Although organized as a military camp, neither Israel nor Hobab, but the ark of the covenant of YHWH seeks, and ultimately finds this rest for the generation that YHWH led from Egypt (cloud). The theme of the ark is significant in Deuteronomy and DH and characteristic of Num 10:33-36, a passage attributed to pre-priestly writers, whose themes recall the theology of Deuteronomy. ${ }^{55}$ If so, this allows for understanding מנוחה in 33b to be part of the rest theme developed in Deuteronomy through Kings.

Numbers 1:1-10:36 describes the first generation as fully compliant in two ways: with the Lord's instructions and the organization of the camp (1:1-10:10; cf. the tabernacle in Exod 35:4-39:43), and its obedient resumption of YHWH's victory march, temporarily halted at Sinai, a march whose destination is defined by the ark seeking a place of rest for Israel (10:11-36). This is the compliant first generation, the obverse of the Janus face. The reverse, that of a non-compliant first generation, begins its depiction in Num 11:1 with the third ויהי which introduces a totally different theme: Israel's complaints and the consequences, neither of which appears in Num 1:1-10:36.

\section{Travel (נסע) in Numbers 11-12}

The itinerary verb נסע appears in Num 11-12, but only in the qatal form: נסעו in 11:35, נסע in 12:15, and 12:16..$^{56}$ Like the qatal (נסע) in Num $10: 17,18,21,22,25$, these forms develop subordinate narrative sequences within the major wayyiqtol sequence. The travel verbs in 11:35 and 12:15, 16 are part of a larger narrative which depicts the consequences of YHWH's hearing Israel's complaints. Thus, Num 11:1-3 depicts Israel's complaints with the

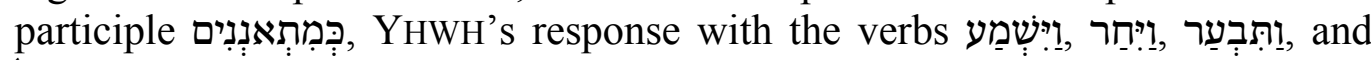
וּתאכַ (11:1; cf. Exod 32:10, 19), and gives the name Taberah to the place where these things happened. An episode initial disjunctive clause in Num 11:4 introduces a new complaint event, apparently at a different location, according to Num 11:35. Travel to or from locations appears to be of secondary interest. ${ }^{57}$

55 Thomas B. Dozeman, "Numbers," NIB 2: 96-97, who understands Num 10:11-28 to be priestly and 10:29-36 to be the beginning of a pre-priestly history which ends in Num 33 (Dozeman, "Numbers," 9-10). The location of 33-36 following the Hobab passage may reflect a post-exilic interest in the ark, i.e., the presence of God, as that which brings Israel to its rest, not the military might of Israel itself. That is, a nonPriestly pentateuchal redactor recontextualized the first cluster with the insertion of the material in 33-36. It is only the second generation that is successful in receiving rest under the guidance of the ark in Joshua, Samuel, and Kings.

56 Artus, Etudes, 24, does not distinguish between the wayyiqtol and qatal forms of נסע. He reads Num 12:16 as describing Israel's arrival.

57 Coats, "Wilderness," 139, notes the difficulty of setting out from the wilderness of Paran in 11:35 and arrival there in 12:16. 
Similarly, Num 12:15 calls attention to Miriam's exclusion from the camp, consequence of her complaint about Moses, as the reason for not traveling. Because the travel verb in Num 12:16 is part of an episode final disjunctive clause, the emphasis falls on the adverb אחר, not on the verb That is, Israel arrived at Paran after the things that occurred between Moses and his siblings. The qatal travel verb and reference to Paran in 12:16 recall the destination depicted in 10:12. ${ }^{58}$ This repetition in the second clause of 12:16 also has the effect of separating the events that took place at Hazeroth from Israel's refusal to enter the land (13-14). From this location Israel moves to spy out the land,

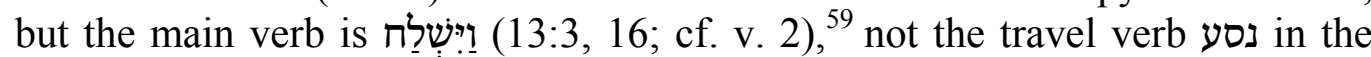
wayyiqtol mode.

\section{$4 \quad$ Summary Conclusions}

I have argued for a reading of Numbers with two itinerary narratives, both of describing the generation that left Egypt, stopped at and a year later departed from Sinai. The two narratives attach different meanings to their stated destinations: מנוחה for God's people, and arrival in Moab; and in terms of Israel's attitude to divine and mosaic instruction: compliant and non-compliant. This leaves the question of the fit of these narratives in the canonical form of Numbers.

\section{TWO ITINERARY NARRATIVES IN NUMBERS: IMPLICATIONS}

The itinerary narratives are secondary to Numbers' overall concern about the future and identity of the second generation of Num 26-36. Moses' words to the trans-Jordan tribes in Num 32:15 suggest the second generation not rebel as did the first generation, but Numbers does not depict this generation as a whole complying with divine instruction (except in the case of the daughters of Zelophehad in 36:10). As the first generation is literarily caught between the antipodes of Egypt and Sinai in Exod 15:22-19:2, and responds positively to

58 Num 10:11-12 and 12:16 "frame[s] the Non-P sequence of travel functioning as a resumptive repetition." Dozeman, "Priestly," 278. But this cannot be an example of resumptive repetition because the two clauses indicating movement in 10:11-12 have different subjects: Israel journeys from (min) the desert of Sinai, but it is the cloud which "dwells" (שכן) in the desert of Paran, not Israel. Resumptive repetition would have to include the cloud indicating the movement. But, as mentioned above, the cloud is not associated at all with any travel notices in Num 11-36. Levine, Numbers, 1-20, 311, agrees on the function of אחר but fails to acknowledge that it opens an episode disjunctive clause, when he writes that "after all is recorded in 10:29-12:15, did the Israelites actually begin their march northward to the Wilderness of Paran."

59 נס 14:25 is also subordinate to the theme of rebellion; the imperative indicates the beginning of the wandering, and the direction of the Sea of Reeds the undoing of the itinerary. But they are not depicted as setting out with the wayyiqtol form until $20: 22$. 
the Sinai instruction in Num 1:1-10:36, so the second generation is literarily liminal: like Exod 19-Lev 27 is followed by its depicted response in Num 1:1-10:36, so Num 11:1-25:18 is followed by 26:1-36:13. But, because the second is not depicted as responding in any way, it is possible, as Dennis Olson argues, that the second generation serves "as a paradigm for each succeeding generation who likewise stands on the edge of the promised land, awaiting the fulfillment of the promises of God. ${ }^{, 60}$ The insertion of Deuteronomy between Numbers and Joshua extends the narrative time to the depiction of the second generation's decision, but at the same time has the effect of reinstructing the second generation in "this law" (Deut 1:5; 4:44; 17:18; 27:3; 31:9; 32:46; cf. Josh 1:7-8) before it leaves Moab under the leadership of Joshua, as the first left Sinai under Moses' leadership (Num 10:13; cf. Num 27:22-23). And, like the first, it follows the ark of the covenant (Josh 3:1-4 [סע in v. 1]; $11 ; 14 ; 4: 18)$, now into the land where it will receive rest from its enemies

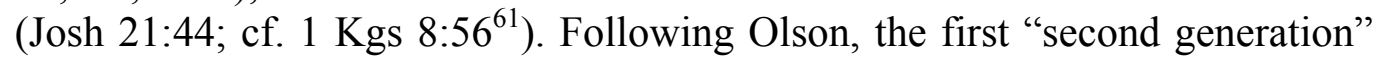
addressed in the canonical Numbers likely are those exiles adrift in the "desert of the nations" (Ezek 20:35), but they are not merely awaiting the fulfillment of divine promises. Rather, from the point of view of Numbers this "second generation" is placed before two modes of behavior before it crosses the river, again. ${ }^{62}$

Numbers' two itinerary narratives provide the second generation two modes of completing their journey to the promised future: one, in compliance with divine and mosaic instruction and following the ark to its provision of rest, as it did for the first second-generation to enter the land (Josh 21:44); and, the other, in willful disobedience to divine and mosaic instruction, ending in the death outside the land consequent upon the worship of other gods, an undeniable memory for the exiles, and for the second second-generation in the land (Judg 2:10). Because in the larger, enneateuchal, narrative the destinations of both travel narratives are depicted as realized, or fulfilled, in modes that are notable deuteronomistic, the two itinerary narratives do not conflict. Rather, they set before the second generation (and the subsequent generations) two ways of completing YHwH's victory march from Egypt through Sinai: to the promised rest at Zion led by the ark, or death in the desert because of apostasy (cf. Ezek 20:35). Thus they also anticipate Deuteronomy's two ways, of life or death (30:11-20). In conclusion, because the first itinerary cluster concludes a

${ }_{61}^{60}$ Olson, Death of the Old, 97.

61 In saying so, Solomon uses the phrase, "Not one word has failed of all the good promises he gave through his servant Moses" (1 Kgs 8:56), which recalls Joshua 21:45: "The Lord gave them rest on every side ... Not one of all the Lord's good promises to the house of Israel failed; everyone was fulfilled."

62 For the exiles the movements evoked by the phrases "across the river" in Josh 24 also reinforce the two modes of completing the journey. 
narrative of compliance, it suggests that the message of Numbers to every second generation is to comply with divine instruction "Today" (Ps 95:7), that it might receive the rest that still remains $(2 \mathrm{Chr} 6: 41){ }^{63}$

\section{BIBLIOGRAPHY}

Artus, Olivier. Etudes sur le livre des Nombres: Récit, Histoire et Loi en Nb 13,120,13. Orbis biblicus et orientalis157. Göttingen: Vandenhoeck \& Ruprecht, 1997.

Ashley, Timothy R. The Book of Numbers. Grand Rapids: Eerdmans, 1993.

Brongers, Hendrik A. I Koningen. De Prediking van het Oude Testament. Nijkerk: G. F. Callenbach, 1963.

Coats, George W. "The Wilderness Itinerary." Catholic Biblical Quarterly 34 (1972): 135-152.

Cross, Frank M. Canaanite Myth and Hebrew Epic: Essays in the History of the Religion of Israel. Cambridge: Cambridge University Press, 1973.

Davies, Graham I. "The Wilderness Itineraries: A Comparative Study." Tyndale Bulletin 25 (1974): 46-81. . "The Wilderness Itineraries and the Composition of the Pentateuch." Vetus Testamentum 33 (1983): 1-13.

Dozeman, Thomas B. "Numbers." Pages 3-268 in vol. 2 of The New Interpreter's Bible. Edited by Leander E. Keck. Nashville: Abingdon, 1998. . "The Priestly Wilderness Itineraries and the Composition of the Pentateuch." Pages 257-288 in The Pentateuch: International Perspectives on Current Research. Edited by Thomas B. Dozeman, Konrad Schmid and Baruch J. Schwarz. Tübingen: Mohr Siebeck, 2011.

Frevel, Christian and Erich Zenger. "Die Bücher Levitikus und Numeri als Teile der Pentateuchkomposition." Pages 35-74 in The Books of Leviticus and Numbers. Edited by Thomas Römer. Louvain: Peeters, 2008.

Goetze, Albrecht. “An Old Babylonian Itinerary.” Journal of Cuneiform Studies 8 (1954): 51-72.

Gradwohl, Roland. "Drei Tage und der dritte Tag." Vetus Testamentum 47 (1997): 373-377.

Gray, George B. A Critical and Exegetical Commentary on Numbers. Edinburgh: T\&T Clark, 1903.

Gray, John. I \& II Kings. Philadelphia: Westminster, 1963.

Heller, Roy L. Narrative Structure and Discourse Constellations: An Analysis of Clause Function in Biblical Hebrew Prose. Harvard Semitic Studies 55. Winona Lake: Eisenbrauns, 2004.

Johnstone, William. "From the Sea to the Mountain. Exodus 15,22-19,2: A CaseStudy in Editorial Techniques. Pages 245-263 in Studies in the Book of Exodus. Edited by Marc Vervenne. Louvain: Peeters, 1996.

Knierim, Rolf P. “The Book of Numbers.” Pages 380-383 in The Task of Old Testament Theology: Method and Cases. Grand Rapids: Eerdmans, 1995.

${ }^{63}$ Von Rad, "There Remains," 101-102. 
Knierim, Rolf P. and George W. Coats. Numbers. Forms of Old Testament Literature 4. Grand Rapids: Eerdmans, 2005.

Leder, Arie C. "The Desert Itinerary Notices of Exodus: Their Narrative, Semiotic, and Theological Functions." Estudios bíblicos 68 (2010): 291-311.

."Hearing Esther after Joshua: Rest in the Exile and the Diaspora." Pages 267-279 in The Book of Joshua and the Land of Israel. Edited by Ed Noort. Bibliotheca ephemeridum theologicarum lovaniensium 250. Louvain: Peeters, 2012.

Lee, Won W. Punishment and Forgiveness in Israel's Migratory Campaign. Grand Rapids: Eerdmans, 2003.

. "The Concept of the Wilderness Journey in the Pentateuch." Pages 1-16 in Israel in the Wilderness: Interpretation of the Biblical Narratives in Jewish and Christian Traditions. Edited by Kenneth E. Pomykala, Leiden: Brill, 2008.

Levin, Christoph. "On the Cohesion and Separation of Books with the Enneateuch." Pages 127-154 in Pentateuch, Hexateuch, or Enneateuch? Identifying Literary Works in Genesis through Kings. Edited by Thomas B. Dozeman, Thomas Römer, and Konrad Schmid. Atlanta: Society of Biblical Literature, 2011.

Levine, Baruch. Numbers 1-20. The Anchor Bible. New York: Doubleday, 1993. Milgrom, Jacob. Numbers. The Jewish Publication Society Torah Commentary. Philadelphia: Jewish Publication Society, 1990.

. Leviticus 1-16: A New Translation with Introduction and Commentary. New York: Doubleday, 1991.

Miller, Patrick D. "The Wilderness Journey in Deuteronomy: Style, Structure, and Theology in Deuteronomy 1-3." Covenant Quarterly 55 (1997): 50-68.

Mulder, Martin J. I Kings 1-11. Volume 1,1 of Kings. Historical Commentary on the Old Testament. Louvain: Peeters, 1998.

Niccacci, Alviero. The Syntax of the Verb in Classical Hebrew Prose. Translated by Wilfred G. E. Watson. Journal for the Study of the Old Testament: Supplement Series 86. Sheffield: Sheffield Academic Press, 1990.

Olson, Dennis T. The Death of the Old and the Birth of the New: The Framework of the Book of Numbers and the Pentateuch. Brown Judaic Studies 71. Chico: Scholars Press, 1985.

Rendtorff, Rolf. Leviticus. Volume 3,1. Neukirchen-Vluyn: Neukirchener Verlag, 1983.

Roskop, Angela R. The Wilderness Itineraries: Genre, Geography and the Growth of the Torah. History, Archaeology, and Culture of the Levant 3. Winona Lake: Eisenbrauns, 2011.

Sakenfeld, Katharine D. Numbers: Journeying with God. Grand Rapids: Eerdmans, 1995.

Seebass, Horst. Numeri 10,11-22,1. Volume 2 of Numeri. Biblischer Kommentar, Altes Testament. Neukirchen: Neukirchener Verlag, 2003.

Smith, Mark S. The Pilgrimage Pattern in Exodus. Sheffield: Sheffield Press, 1997.

Swanepoel, Marius G. "Die 'drie dae'-motief in die Ou Testament (BHS)." Nederduitse gereformeerde teologiese tydskrif 32 (1991): 541-551.

Talstra, Eep. "A Hierarchy of Clauses of Biblical Hebrew Narrative." Pages 85-118 in Narrative Syntax in the Hebrew Bible: Papers of the Tilburg Conference 1996. Edited by Ellen Van Wolde. Biblical Interpretation Series 29. Leiden: Brill, 1997. 
534 Leder, "From the Mountain of YHWH," OTE 29/3 (2016): 513-534

Terrien, Samuel. The Elusive Presence: The Heart of Biblical Theology. San Francisco: Harper \& Row, 1978.

Von Rad, Gerhard. "There Remains Still a Rest for the People of God: An Investigation of a Biblical Conception." Pages 94-102 in The Problem of the Hexateuch and other Essays. Edited by Gerhard von Rad. Translated by E. W. Trueman Dicken. London: SCM, 1966.

Walsh, Jerome T. "From Egypt to Moab: A Source-Critical Analysis of the Wilderness Itinerary." Catholic Biblical Quarterly 39 (1977): 20-33.

Waltke, Bruce K. and Michael O'Connor. An Introduction to Biblical Hebrew Syntax. Winona Lake: Eisenbrauns, 1990.

Watts, James W. Psalm and Story: Inset Hymns in Hebrew Narrative. Journal for the Study of the Old Testament 139. Sheffield: Sheffield Academic Press, 1992.

Wenham, Gordon J. Numbers. Leicester: InterVarsity, 1981.

Zenger, Erich, Georg Braulik, Herbert Niehr, Georg Steins, Helmut Engel, Ludger Schwienhorst-Schönberger, Silvia Schroer, Johannes Marböck, Hans-Winfried Jüngling, Ivo Meyer, and Frank-Lothar Hossfeld. Einleitung in das Alte Testament. Band 1,1. Stuttgart: Kohlhammer, 1995.

Arie C. Leder, Research Fellow, University of the Free State, Bloemfontein, Martin J. Wyngaarden Senior Professor of OT Studies, emeritus, Calvin Theological Seminary, Grand Rapids, Mich., lede@calvinseminary.edu. 